\title{
Vibration Analysis of Uniform and Tapered Composite Beams with Embedded Shape Memory Alloy
}

\author{
Qasim Abbas Atiyah \\ Ammar Saleem Hameed \\ Baqer Jabbar Assi \\ Mechanical Engineering Department, University of Technology, Baghdad-Iraq
}

20044@uotechnology.edu.iq 20086@uotechnology.edu.iq aquer92jabbar@gmail.com

\begin{tabular}{|l|l|l|}
\hline Submission date:- 26/12/2018 & Acceptance date:- 13/1/2019 & Publication date:- 15/1/2019 \\
\hline
\end{tabular}

\begin{abstract}
In this study, laminated composite materials were hybridized with E-glass fiber and Nitinol (Nickel-Titanium) wires. Hand lay-up technique was used to prepare the samples, epoxy resin type (Sikadur $52 \mathrm{~N}$ ) was used as matrix reinforced by one fiber from E-glass fiber woven roving with embedded nitinol wires with a diameter $0.5 \mathrm{~mm}$ for samples and number of wires such as $0,1,3,5$ and 9 to find the effect of the number of wires on the natural frequency. The samples were fixed as a cantilever beam. The effects of increasing the number of nitinol wires, the diameter of nitinol wires, the length of the cantilever beam and the thickness of beam on the natural frequencies of the beam were studied. Also, the effects of the tapered in width side and thickness side on the natural frequencies of cantilever beam were studied. The results showed that the increasing in the number of nitinol wires and the diameter of nitinol wires lead to decrease the natural frequency in martensite phase and increase the natural frequency in austenite phase. Also, the increasing in thickness of beam and width ratio of the beam lead to increase the natural frequency. As well as, the increasing in the thickness ratio leads to increase the first natural frequency and decrease the second and third ones. In addition, the increasing in the length of the beam decreases the natural frequency.
\end{abstract}

Key words: Shape Memory Alloy (SMA), Cantilever beam, Natural frequency.

\begin{tabular}{|c|c|c|}
\hline Symbol & Definition & Units \\
\hline$A$ & Cross section area of the specimen & $\mathrm{mm}^{2}$ \\
\hline$b_{\text {in }}$ & Width of root side of cantilever beam & $\mathrm{mm}$ \\
\hline bout & Width of free side of cantilever beam & $\mathrm{mm}$ \\
\hline$E_{c}, E_{m}, E_{r}$ & $\begin{array}{l}\text { Modulus of elasticity of composite material, epoxy } \\
\text { and fiber }\end{array}$ & $\mathrm{MPa}$ \\
\hline$E_{b}$ & Modulus of elasticity of the beam & $\mathrm{MPa}$ \\
\hline$E_{n}$ & The modules of elasticity of the nitinol wire & $\mathrm{MPa}$ \\
\hline$h_{\text {in }}$ & Thickness of root side of cantilever beam & $\mathrm{mm}$ \\
\hline$h_{\text {out }}$ & Thickness of free side of cantilever beam & $\mathrm{mm}$ \\
\hline$I$ & Cross section moment of inertia & $\mathrm{mm}^{4}$ \\
\hline$\xi_{c}, \xi_{m}, \xi_{r}$ & $\begin{array}{l}\text { Volume fraction of composite material, epoxy and } \\
\text { fiber }\end{array}$ & \\
\hline$\xi_{n}$ & $\begin{array}{l}\text { The ratio of the total cross sectional area of wires to } \\
\text { the cross sectional area of the beam. }\end{array}$ & \\
\hline$\rho_{c}, \rho_{m}, \rho_{r}$ & $\begin{array}{l}\text { The density of the composite material, epoxy and } \\
\text { fiber }\end{array}$ & $\mathrm{Kg} / \mathrm{m}^{3}$ \\
\hline$\rho_{n}$ & The density of the nitinol & $\mathrm{Kg} / \mathrm{m}^{3}$ \\
\hline$\rho_{b}$ & The density of the specimen & $\mathrm{Kg} / \mathrm{m}^{3}$ \\
\hline$\omega_{n}$ & The natural frequency & $\mathrm{rad} / \mathrm{sec}$ \\
\hline Width ratio & $\begin{array}{l}\text { The ratio width of root side of cantilever beam to } \\
\text { width of free side of cantilever beam }\left(b_{\text {in }} / b_{\text {out }}\right)\end{array}$ & \\
\hline $\begin{array}{l}\text { Thickness } \\
\text { ratio }\end{array}$ & $\begin{array}{l}\text { The ratio thickness of root side of cantilever beam to } \\
\text { thickness of free side of cantilever beam }\left(h_{\text {in }} / h_{\text {out }}\right)\end{array}$ & \\
\hline
\end{tabular}




\section{Introduction}

Recently, Shape Memory Alloys (SMAs) have been on the front of research due to that the SMAs are unique alloys having ability to remember an original shape after being deformed. The natural frequencies have a big influence on the design of system that exposed to vibrations because when the system worked at a frequency near to the natural frequencies, the acceleration will be at the highest value, which lead to the failure of the system. Lau et al. [1] estimated the natural frequency of glass fiber composite beams with embedded shape memory alloy (SMA) wires. The results showed the natural frequencies of all the beams decrease with increasing number of SMA wires in martensitic phase. Dezfuli et al. [2] used the nitinol wires as reinforcement, into plate made up Aluminum as a matrix. The results showed the phase transformation starting from martensite to austenite phase and that led to increasing in the stiffness of the plate, which results in increasing in the natural frequency. M. Yuvaraja and M. Senthilkumar [3] compared between utilizing piezoelectric (PZT) based and SMA wires composites on the vibration characteristics. The smart composite cantilever beam contains a glass fiber reinforced polymer (GFRP) with attached SMAs externally and with surface bonded PZT. The results demonstrated using SMA wires is more effective than using PZT. Cem and Mustafa [4] investigated the free vibration analysis on a blade of Air X 4140W horizontal axis wind turbine. 4140 steel, shape memory alloys (Ni-Ti, $\mathrm{Cu}-\mathrm{Zn}-\mathrm{Al}$ and $\mathrm{Cu}-\mathrm{Al}-\mathrm{Ni}$ ) in blade root connection was used. The results showed that the maximum total deformation was observed in the fifth mode of the natural frequency for the blade root connection from $\mathrm{Cu}-\mathrm{Zn}-\mathrm{Al}$ alloy. Gupta et al. [5] studied the effect of shape memory alloys to increase the damping of glass fiber reinforced plastic (GFRP) composites. The results exhibited the damping ratio of SMA hybrid composite beam was found to be higher as compared to the pristine and steel hybrid GFRP composite beam.

The main target of this work is to study the effect of the number and diameter of nitinol wires and the length, thickness, width ratio and thickness ratio of cantilever beams on the natural frequency.

\section{Experimental work}

\subsection{Used Materials}

The materials used to prepare the samples consist of epoxy resin as a matrix (type Sikadur 52 $\mathrm{N}$ ), Table (4.1) lists the properties of the epoxy used in this work [6]. And two reinforced composite materials, which are shape memory alloy wires (Nitinol), a near ideal 50/50 combination of nickel and titanium. The diameters used of nitinol wires are $0.5 \mathrm{~mm}$. Table (4.2) contains the physical properties of Nitinol [7] and E-glass fiber woven roving. Table (4.3) lists the properties of the fibers type E-glass [8].

Table (1): The properties of epoxy [6]

\begin{tabular}{|c|c|}
\hline Properties & Values \\
\hline Density $\left(\mathbf{k g} / \mathbf{m}^{\mathbf{3}}\right)$ & 1100 \\
\hline Modulus of Elasticity (MPa) & 1800 \\
\hline Poisson's Ratio & 0.35 \\
\hline
\end{tabular}

Table (3): The properties of the E-glass [8]

\begin{tabular}{|c|c|}
\hline Properties & Values \\
\hline Density $\left(\mathbf{k g} / \mathbf{m}^{\mathbf{3}}\right)$ & 2580 \\
\hline Modulus of Elasticity (MPa) & 72000 \\
\hline Poisson's Ratio & 0.22 \\
\hline
\end{tabular}

Table (2): Properties of the nitinol wire [7]

\begin{tabular}{|c|c|}
\hline Properties & Values \\
\hline Melting point $\left({ }^{\circ} \mathbf{C}\right)$ & $1240-1310$ \\
\hline Density $\left(\mathbf{k g} / \mathbf{m}^{3}\right)$ & 6450 \\
\hline Modulus of Elasticity $(\mathbf{G P a})$ & 28 (martensite) \\
\cline { 2 - 2 } & 70 (austenite) \\
\hline Poisson's Ratio & 0.33 \\
\hline Austenite start temperature $\left(\mathbf{A}_{\mathbf{s}}\right){ }^{\circ} \mathbf{C}$ & $32-36^{\circ} \mathrm{C}$ \\
\hline Austenite finish temperature $\left(\mathbf{A}_{\mathbf{f}}\right){ }^{\circ} \mathbf{C}$ & $45^{\circ} \mathrm{C}$ \\
\hline
\end{tabular}




\subsection{Samples}

The technique used to form the samples is hand lay-up. The uniform samples have dimensions (220 $\mathrm{mm} \times 50 \mathrm{~mm} \times 4 \mathrm{~mm}$ ), as shown in figure (1), while the tapered samples are designed as follows: the width of root side is constant $50 \mathrm{~mm}$ and the width of free side is variable $(20 \mathrm{~mm}, 30 \mathrm{~mm}$ and 40 $\mathrm{mm}$ ), the thickness is $4 \mathrm{~mm}$ and the length is $220 \mathrm{~mm}$, in all samples the length decreases $20 \mathrm{~mm}$ for fixation.

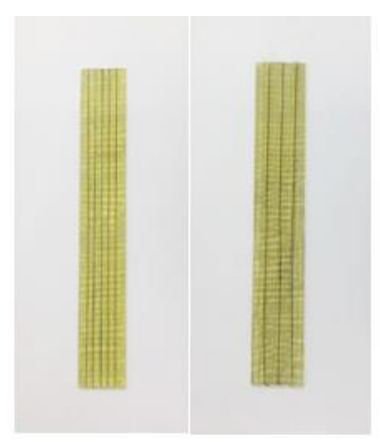

Figure (1): Samples of composite materials with embedded nitinol wires

\subsection{Vibration Test}

The vibration system was used to find the natural frequency, see figure (2).

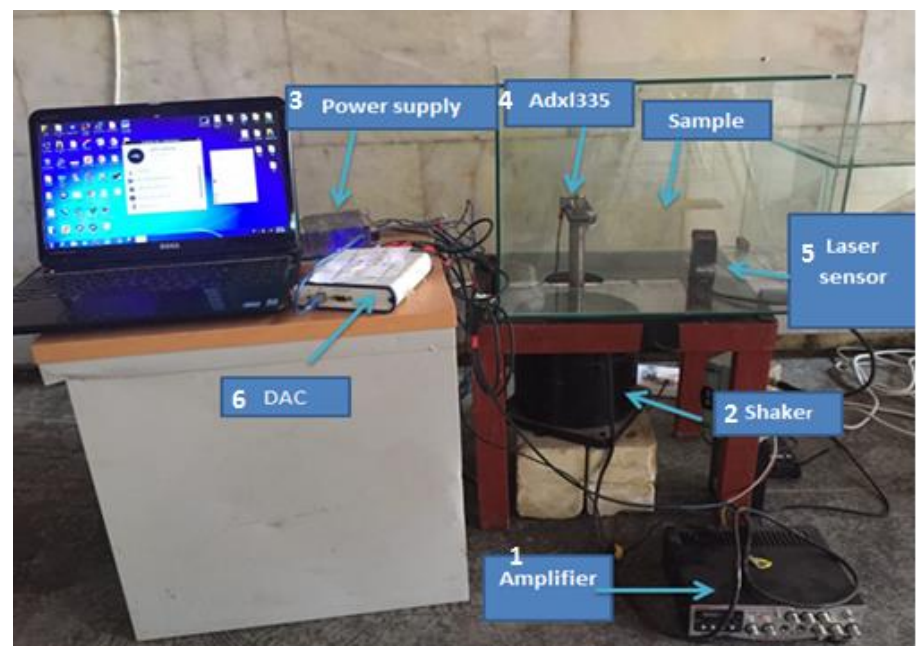

Figure (2): Vibration system

The experimental frequency-amplitude curve was found from Fast Fourier Transformation (FFT) screen by using LABVIEW program in vibration system test, see figure (3).

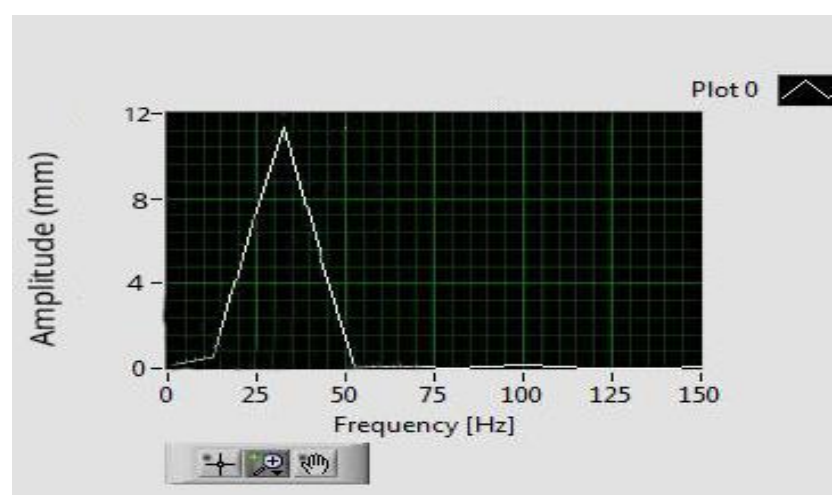

Figure (3): Output of Fast Fourier Transformation (FFT) analyze. 


\section{Theoretical Analysis}

\subsection{Rule of Mixture}

This rule was used to estimate the density and modulus of elasticity.

The density and the modulus of elasticity of the composite beam (epoxy and E-glass fiber) is calculated from the these equation [9]

$\rho_{c}=\sum \rho * \xi=\rho_{m} * \xi_{m}+\rho_{r} * \xi_{r}$

$E_{c}=E_{m} \xi_{m}+E_{\mathrm{r}} \xi_{\mathrm{r}}$

The density and the modulus of elasticity of beam, which consists of composite materials and nitinol wires is calculated from these equations [1]

$\rho_{b}=\rho_{c}+\left(\rho_{n}-\rho_{c}\right) * \xi_{n}$

$E_{b}=E_{c}+\left(E_{n}-E_{c}\right) * \xi_{n}$

\subsection{Exact solution of natural frequency of cantilever beam}

When the beam is uniform and assumed cantilever beam as Euler-Bernoulli beam as shown in figure (4).
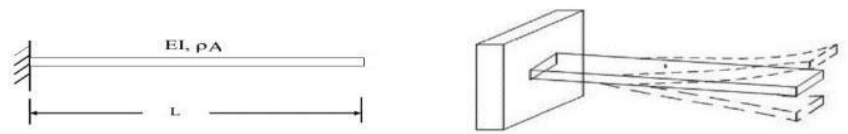

\section{Figure (4): Cantilever beam}

The natural frequencies can be found from the equation [10]:

$$
\omega_{n}=\left(\frac{2 n-1}{2} \pi+e_{n}\right)^{2} * \frac{1}{l^{2}} * \sqrt{\frac{E I}{\rho A}}(\mathrm{rad} / \mathrm{sec})
$$

$\mathrm{n}=1,2 \ldots \infty$

Where $e_{n}$ is small correction terms and obtained $e_{1}=0.3042, e_{2}=-0.018, e_{3}=0.001$

The unit of the natural frequency is converted from $(\mathrm{rad} / \mathrm{sec})$ to $\mathrm{Hz}$ by the following equation:

$f_{n}=\frac{\omega_{n}}{2 \pi}=\frac{1}{2 \pi} *\left(\frac{2 n-1}{2} \pi+e_{n}\right)^{2} * \frac{1}{l^{2}} * \sqrt{\frac{E I}{\rho A}}$

\subsection{Finite Element Analysis (FEA)}

ANSYS Workbench software, version 17, is for the finite element analysis to investigate the natural frequencies and its vibration mode shapes, see figure (5).

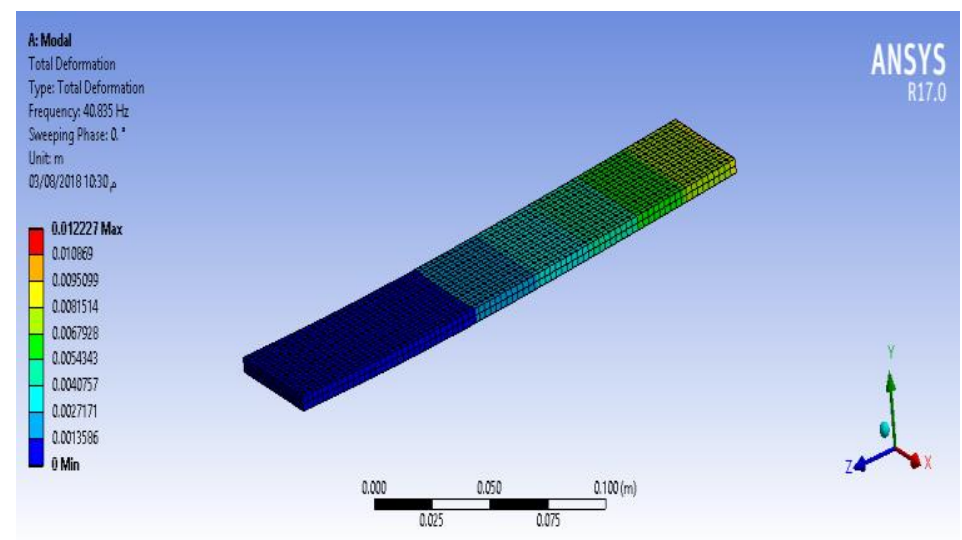

Figure (5): First mode shape, modal response of the uniform cantilever composite beam 


\section{Results and Discussions}

\subsection{The Density and Modulus of Elasticity}

The rule of mixtures was used to calculate the density and the modulus of elasticity for uniform beam.

In figures (6 and 7), the samples contain epoxy reinforced by E-glass fiber layer with embedded nitinol wires. In figure (6) the density increased by $7.74 \%$ if the number of embedded nitinol wires rose from 1 to 20 wires. And in figure (7) the modulus of elasticity increased by $5.02 \%$ if the number of embedded nitinol wires rose from 1 to 20 in the phase of martensite, also the modulus of elasticity increased by $13.914 \%$ the number of embedded nitinol wires raised from 1 to 20 in the phase of austenite.

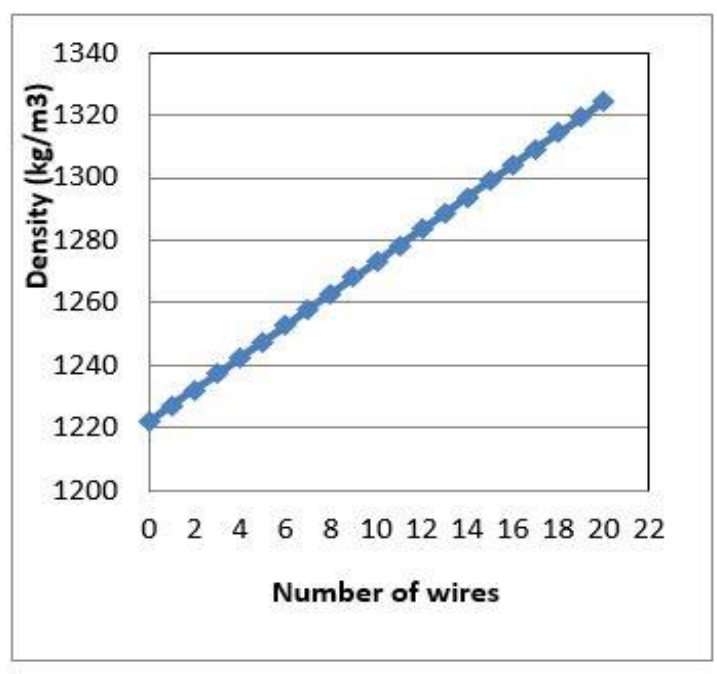

Figure (6): The variation of density with the number of nitinol wires

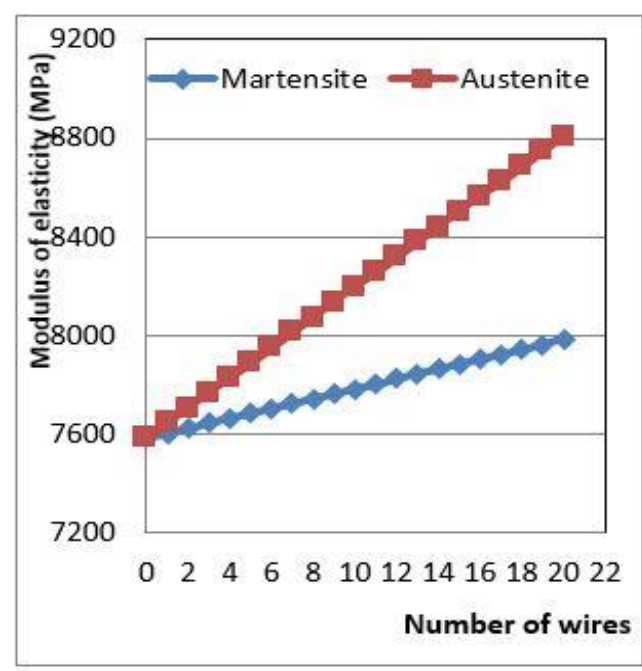

Figure (7): The variation of modulus of elasticity with number of nitinol wires

\subsection{The natural frequency of uniform cantilever beam}

Table (4) reveals the verification of the results, which include the theoretical results of the density, the theoretical results of the modulus, and the theoretical, numerical and experimental results of the vibration natural frequency modes. Theoretical results of natural frequency were found from the equation (6). 
Table (4): Composite materials containing epoxy reinforced by E-glass fiber layer with embedded nitinol wires and its diameter $0.5 \mathrm{~mm}$ (martensite phase).

\begin{tabular}{|c|c|c|c|c|c|c|c|c|}
\hline \multirow[b]{2}{*}{$\begin{array}{l}\text { Numb } \\
\text { ers of } \\
\text { wires }\end{array}$} & \multirow[b]{2}{*}{$\begin{array}{l}\text { Density } \\
\left(\mathrm{kg} / \mathrm{m}^{3}\right)\end{array}$} & \multirow[b]{2}{*}{$\begin{array}{c}E_{\text {beam }} \\
(\mathrm{MPa})\end{array}$} & \multirow[b]{2}{*}{$\begin{array}{l}\text { Mo } \\
\text { des }\end{array}$} & \multicolumn{5}{|c|}{ Natural frequency $(\mathrm{Hz})$} \\
\hline & & & & $\begin{array}{l}\text { Experime } \\
\text { ntal }\end{array}$ & $\begin{array}{c}\text { Theoreti } \\
\text { cal }\end{array}$ & ANSYS & $\begin{array}{c}\text { Error\% } \\
\text { With } \\
\text { Theo. }\end{array}$ & $\begin{array}{c}\text { Error\% } \\
\text { With } \\
\text { ANSYS }\end{array}$ \\
\hline \multirow{3}{*}{0} & \multirow{3}{*}{1221.89} & \multirow{3}{*}{$\begin{array}{c}7581 . \\
9\end{array}$} & 1 & 33.3 & 40.234 & 40.835 & 17.23 & 18.45 \\
\hline & & & 2 & 222.5 & 252.206 & 254.99 & 11.7 & 12.7 \\
\hline & & & 3 & 662.5 & $\begin{array}{c}706.134 \\
9\end{array}$ & 713.86 & 6.17 & 7.19 \\
\hline \multirow{3}{*}{1} & \multirow{3}{*}{1227.022} & \multirow{3}{*}{$\begin{array}{c}7601 . \\
94\end{array}$} & 1 & 33.4 & 40.203 & 40.803 & 16.9 & 18.14 \\
\hline & & & 2 & 222.5 & 252.010 & 254.79 & 11.7 & 12.67 \\
\hline & & & 3 & 662.4 & 705.044 & 713.3 & 6.04 & 7.13 \\
\hline \multirow{3}{*}{3} & \multirow{3}{*}{1237.287} & \multirow{3}{*}{$\begin{array}{c}7642 . \\
03\end{array}$} & 1 & 33.2 & 40.141 & 40.741 & 17.29 & 18.5 \\
\hline & & & 2 & 221.9 & 251.623 & 254.4 & 11.81 & 12.77 \\
\hline & & & 3 & 660.9 & 704.504 & 713.21 & 6.18 & 7.33 \\
\hline \multirow{3}{*}{5} & \multirow{3}{*}{1247.55} & \multirow{3}{*}{$\begin{array}{c}7682 . \\
12\end{array}$} & 1 & 33.2 & 40.080 & 40.67 & 17.16 & 18.36 \\
\hline & & & 2 & 221.7 & 251.242 & 254.01 & 11.75 & 12.71 \\
\hline & & & 3 & 660 & 703.438 & 711.13 & 6.17 & 7.18 \\
\hline \multirow{3}{*}{9} & \multirow{3}{*}{1268.082} & \multirow{3}{*}{$\begin{array}{c}7762 . \\
3\end{array}$} & 1 & 33 & 39.961 & 40.559 & 17.41 & 18.63 \\
\hline & & & 2 & 220.8 & 250.497 & 253.26 & 11.85 & 12.81 \\
\hline & & & 3 & 657.1 & 701.352 & 709.02 & 6.3 & 7.32 \\
\hline
\end{tabular}

\subsubsection{The effect of the numbers of nitinol wires}

The samples of the figures (8), (9) and (10) are containing epoxy and one E-glass fiber layer with changing the numbers of wires (diameter is $0.5 \mathrm{~mm}$ ) that embedded in the samples. The results of these figures were calculated theoretically by equation (6). Figures (8), (9) and (10) illustrate the behavior of changing the beam natural frequencies which embedded with SMA wires in two phases, the first is nitinol wires totally martensite, and the second is nitinol wires totally austenite, for martensite case, the initial 3 natural frequencies decreased by $1.44 \%$ if embedded nitinol wires raised from 1 to 20 wires. And in austenite phase, the initial 3 natural frequencies raised by $3.39 \%$ if embedded nitinol wires raised from 1 to 20 .

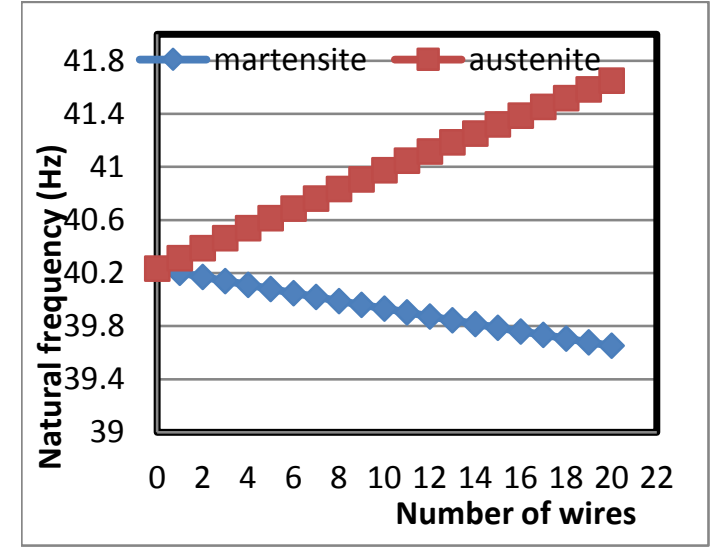

Figure (8): The variation of first natural frequencies with numbers of embedded nitinol wires

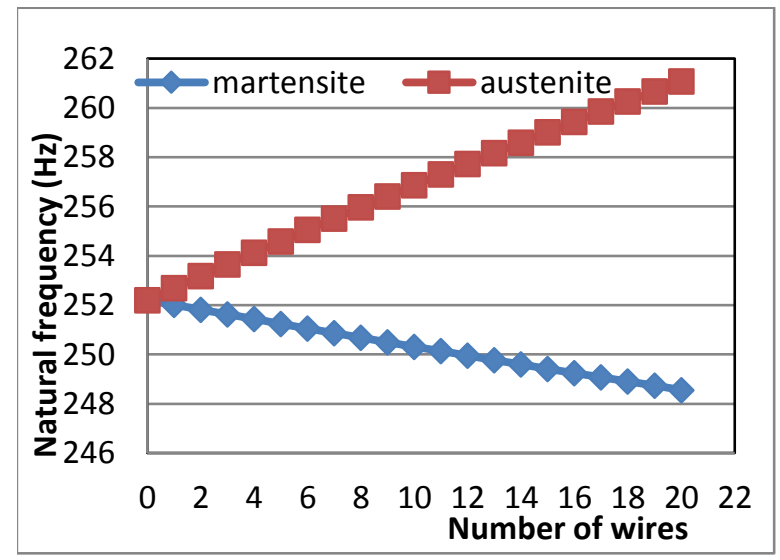

Figure (9): The variation of second natural frequencies with numbers of embedded nitinol wires 


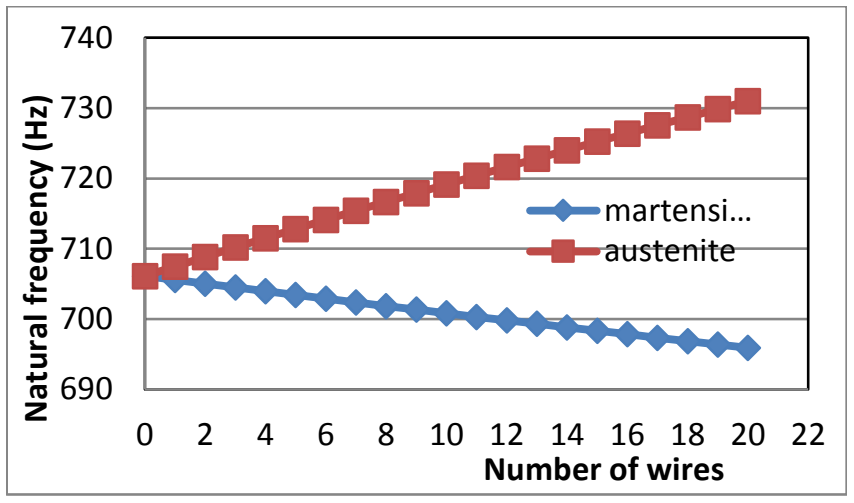

Figure (10): The variation of third natural frequencies with numbers of embedded nitinol

wires

\subsubsection{The effect of the diameter of nitinol wires}

Figures (11), (12) and (13) elucidate the behavior of changing the natural frequencies of epoxy reinforced by one E-glass fiber layer and embedded by three nitinol wires with increased diameters of these three wires at martensite and austenite phases. The results of these figures were calculated theoretically by equation (6).

for martensite case, the initial 3 natural frequencies decreased by $6.79 \%$ if diameter of the embedded nitinol wires was raised from $0.5 \mathrm{~mm}$ to $3.3 \mathrm{~mm}$. And in austenite phase, the initial 3 natural frequencies raised by $13.20 \%$ if diameter of the embedded nitinol wires was increased from $0.5 \mathrm{~mm}$ to $3.3 \mathrm{~mm}$.

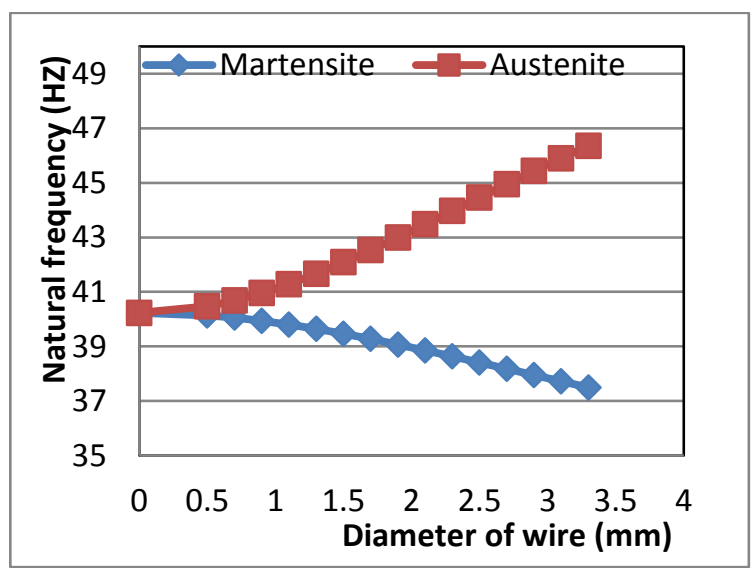

Figure (11): The variation of first natural frequencies vs diameter of embedded nitinol wires

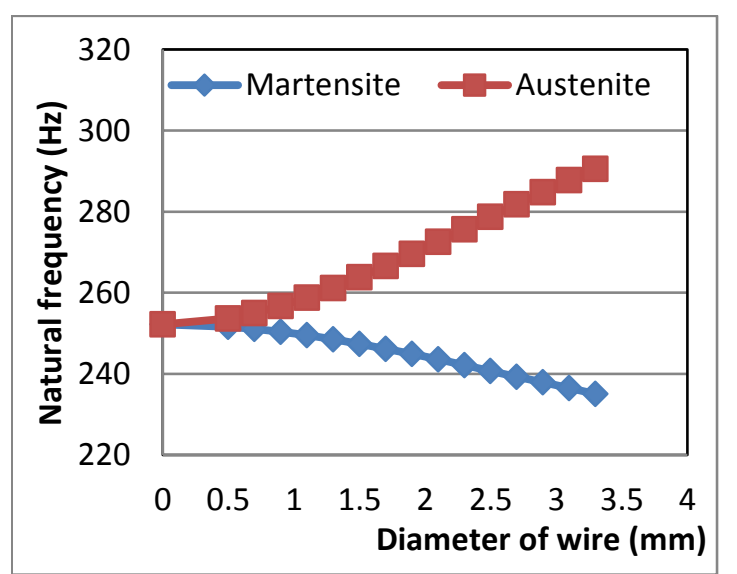

Figure (12): The variation of second natural frequencies with diameter of embedded nitinol wires 


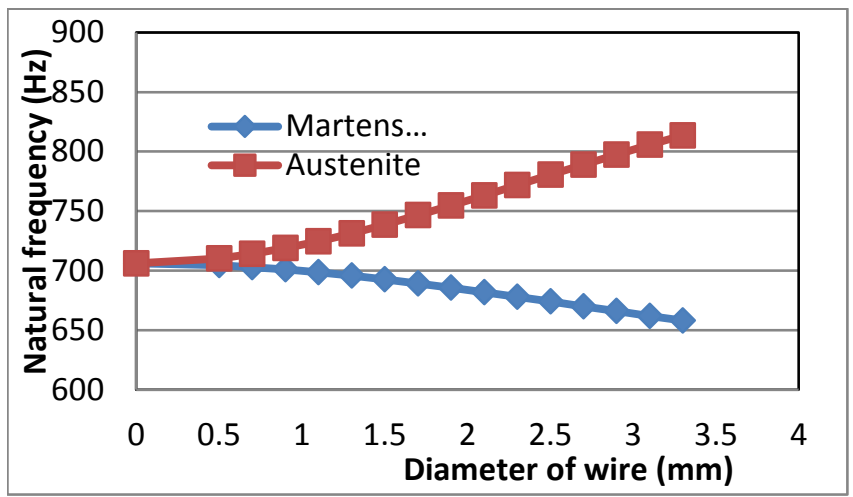

Figure (13): The variation of third natural frequencies with diameter of embedded nitinol wires

\subsubsection{The effect of the length of the beam}

Figure (14) displays the trend of changing the cantilever natural frequencies of composite of epoxy reinforced via one E-glass fiber layer with increased length of beam. The results of this figure were calculated theoretically by equation (6). In this figure, if the beam length is increased, the natural frequencies will decrease in all modes. The initial 3 natural frequencies reduced by $75 \%$ if increasing length of beam from $200 \mathrm{~mm}$ to $400 \mathrm{~mm}$.

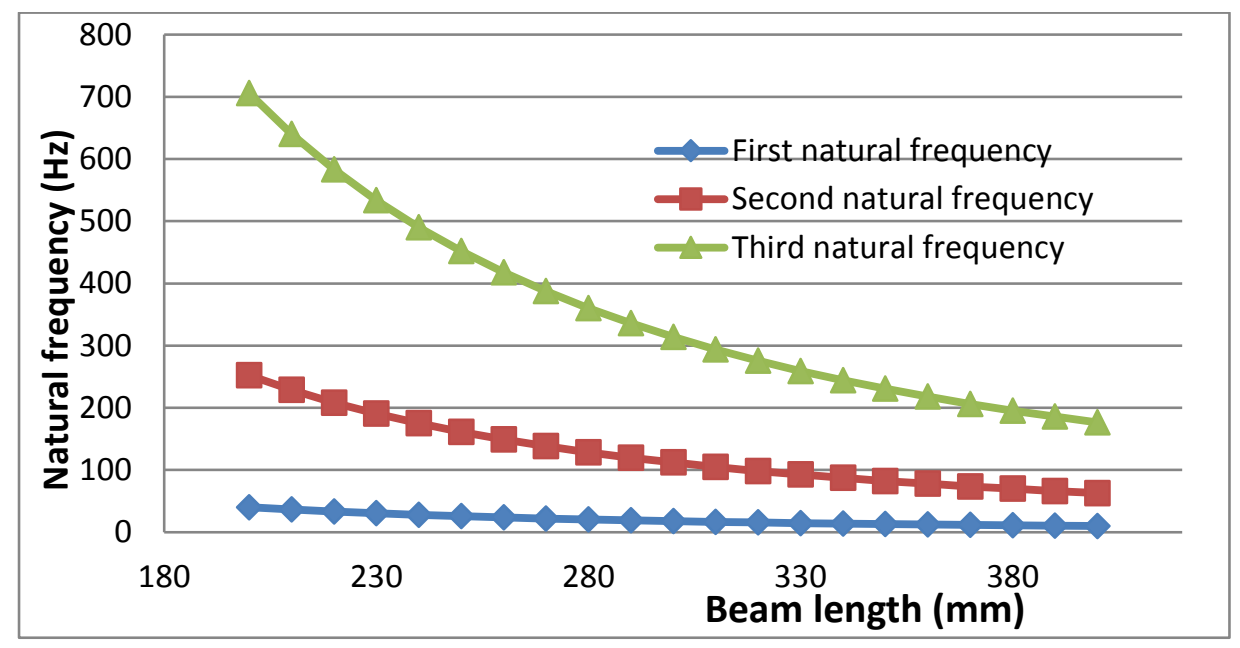

Figure (14): The variation of the first three natural frequencies with length of beam

\subsubsection{The effect of the thickness of the beam}

Figure (15) clarifies the relation between the thickness of beam containing epoxy and one Eglass fiber layer with the first three natural frequencies. The results of this figure were calculated theoretically by equation (6).

In this figure the increasing in thickness leads to increasing in the natural frequencies. The first three natural frequencies rose by $50 \%$ if the thickness was raised from (2-4) mm. 


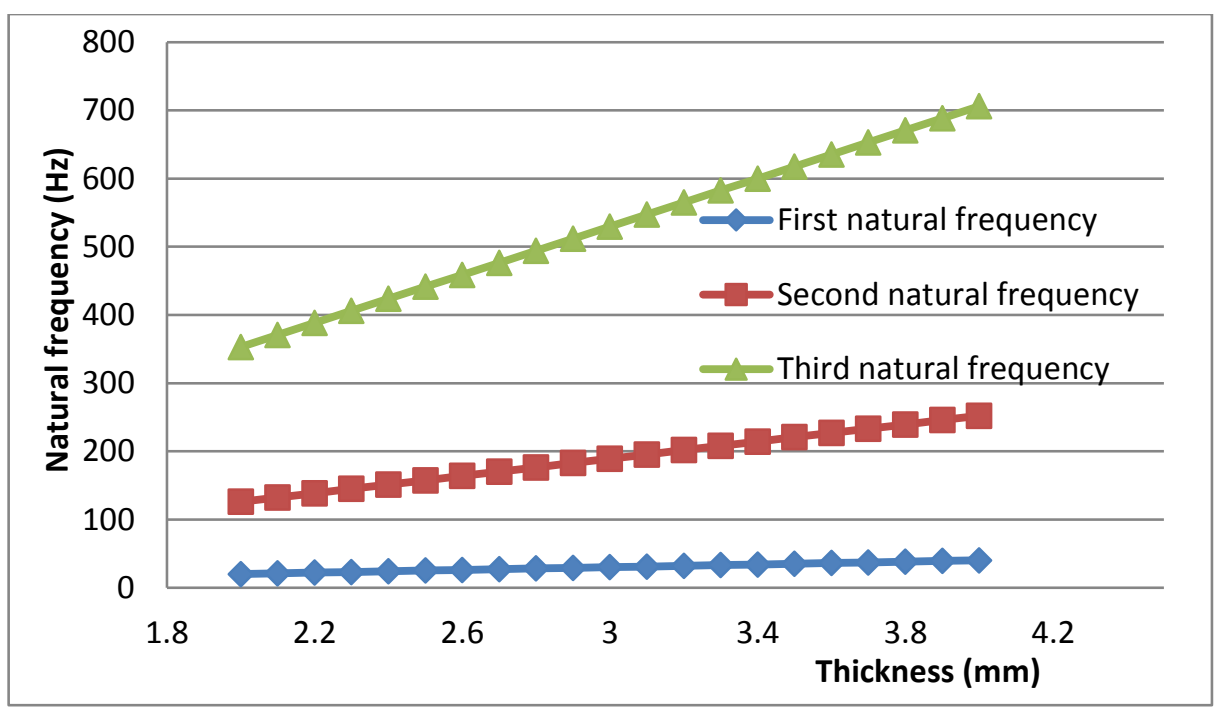

Figure (15): The variation of first three natural frequencies with thickness of beam

\subsection{The results and discussion of the tapered cantilever beam}

Table (5) show of the theoretical results of the density, the theoretical results of the modulus of elasticity, the verification from the experimental natural frequency, and with numerical methods by using ANSYS program. And, in all these tables, the cantilever beam is containing epoxy reinforced by E-glass fiber layer.

Table (5): Effect of width ratio on the natural frequency of composite beam

\begin{tabular}{|c|c|c|c|c|c|c|}
\hline \multirow{2}{*}{$\begin{array}{c}\text { Width ratio } \\
\left(\mathbf{b}_{\text {in }} / \mathbf{b}_{\text {out }}\right)\end{array}$} & \multirow{2}{*}{$\begin{array}{l}\text { Density } \\
\left(\mathbf{k g} / \mathbf{m}^{3}\right)\end{array}$} & \multirow{2}{*}{$\begin{array}{c}\mathbf{E}_{\text {beam }} \\
\text { (MPa) }\end{array}$} & \multirow[b]{2}{*}{ Mode } & \multicolumn{3}{|c|}{ Natural frequency (Hz) } \\
\hline & & & & Experimental & ANSYS & $\begin{array}{c}\text { Error with } \\
\%\end{array}$ \\
\hline \multirow{3}{*}{$\mathbf{5 0 / 5 0}$} & \multirow{3}{*}{1221.89} & \multirow{3}{*}{7581.9} & 1 & 33.3 & 40.835 & 18.45 \\
\hline & & & 2 & 222.5 & 254.99 & 12.7 \\
\hline & & & 3 & 662.5 & 713.86 & 7.19 \\
\hline \multirow{3}{*}{$50 / 40$} & \multirow{3}{*}{1221.89} & \multirow{3}{*}{7581.9} & 1 & 35.4 & 43.644 & 18.88 \\
\hline & & & 2 & 227.6 & 260.15 & 12.51 \\
\hline & & & 3 & 665.7 & 718.12 & 7.29 \\
\hline \multirow{3}{*}{$50 / 30$} & \multirow{3}{*}{1221.89} & \multirow{3}{*}{7581.9} & 1 & 38.3 & 47.451 & 19.28 \\
\hline & & & 2 & 234.5 & 266.96 & 12.15 \\
\hline & & & 3 & 669.5 & 724.05 & 7.53 \\
\hline \multirow{3}{*}{$50 / 20$} & \multirow{3}{*}{1221.89} & \multirow{3}{*}{7581.9} & 1 & 42.6 & 53.028 & 19.66 \\
\hline & & & 2 & 240.6 & 276.99 & 13.13 \\
\hline & & & 3 & 672.3 & 733.78 & 8.37 \\
\hline
\end{tabular}

4.3.1 The effect of variation of tapered cantilever beam width ratio on the natural frequency

Figure (16) shows the relation between first three natural frequencies with width ratio of cantilever beam contain epoxy and E-glass fiber layer by ANSYS program. In this figure the first three natural frequencies increased by $22.9 \%, 7.9 \%$ and $2.7 \%$, respectively if the ratio width was raised from $(1-2.5) \mathrm{mm}$. 


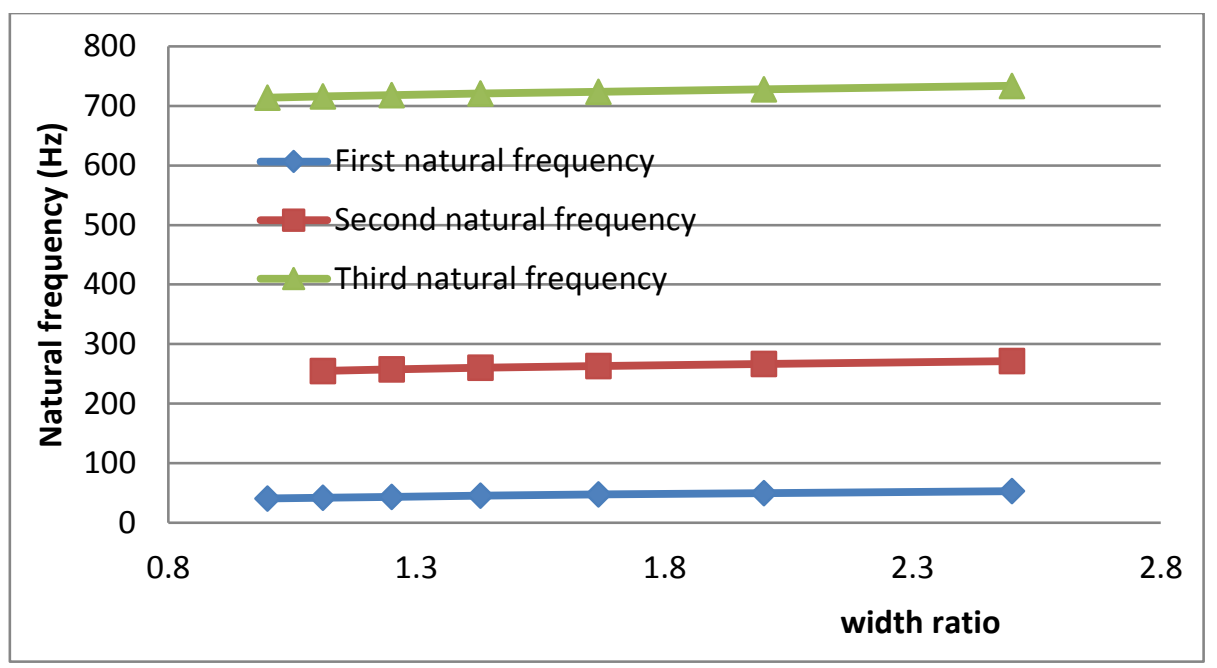

Figure (16): The variation of first three natural frequencies with width ratio (bin/bout)

\subsubsection{The effect of variation of tapered cantilever beam thickness ratio on the natural frequency}

Figure (17) elucidate the relation between first three natural frequencies and width ratio of cantilever beam containing epoxy and E-glass fiber layer by ANSYS program. The first natural frequency increased by $11 \%$, and the second natural frequency decreased by $21.4 \%$ the third natural frequency decreased by $29.7 \%$ when the thickness ratio was increased from 1 to 2.666 .

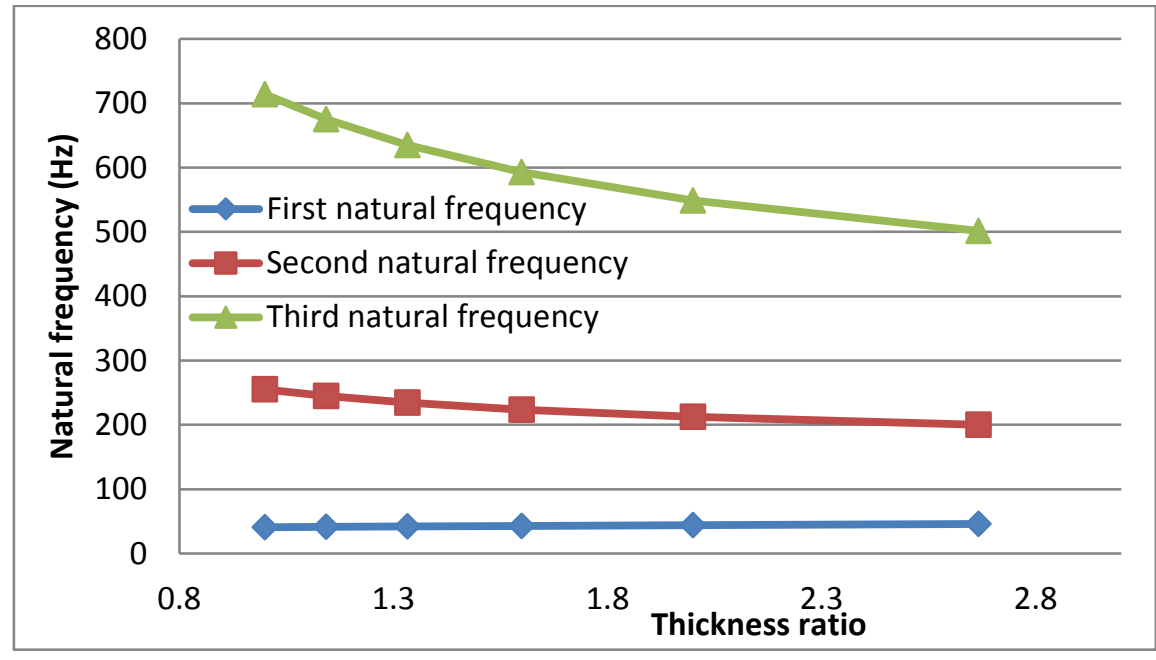

Figure (17): The variation of first three natural frequencies with thickness ratio

$$
\left(\mathbf{h}_{\text {in }} / \mathbf{h}_{\text {out }}\right)
$$

\section{Conclusions}

The major goals of this work are to study the effect of the geometrical and mechanical properties on the natural frequency of uniform and tapered cantilever beam:

1. Increasing the number and the diameter of nitinol wires which embedded in the composite beam leads to decrease the natural frequency in martensite phase and leads to increase the natural frequency in austenite phase.

2. Increasing the thickness of the cantilever composite beam leads to increase the natural frequencies. Also, increasing the length of the beam leads to decrease the natural frequencies.

3. Increasing width ratio of the tapered cantilever beam embedded with shape memory alloy leads to increase the natural frequencies. 
4. Increasing thickness ratio of the tapered cantilever beam embedded with shape memory alloy leads to increase the first natural frequency and decrease the second and third natural frequencies.

\section{CONFLICT OF INTERESTS.}

- There are no conflicts of interest.

\section{References}

[1] Kin-tak Lau, Li-min Zhou, and Xiao-ming Tao, "Control of Natural Frequencies of a ClampedClamped Composite Beam with Embedded Shape Memory Alloy Wires", Elsevier, Composite Structures, Vol. 58, pp. 39-47, 2002.

[2] F. Hedayati Dezfuli, S. Khalilian, A. Abedian, "Dynamic control of plate with embedded shape memory alloy wires", 27th International Congress of the Aeronautical Sciences, 2010.

[3] Yuvaraja and M. Senthilkumar, "Comparative Study on Vibration Characteristics of a Flexible GFRP Composite Beam Using SMA and PZT Actuators”, Manuf. and Ind. Eng., Vol. 11, pp. 2833, 2012.

[4] Cem Emekiz and Mustafa Tufan Altunok, "Free Vibration Analysis of Shape Memory Alloys Used In Wind Turbine Blade Root Connection", International Refereed Journal of Engineering and Science (IRJES), Vol. 5, pp. 11-17, 2016.

[5] Amit Kumar Gupta, R. Velmurugan and Makarand Joshi, "Comparative Study of Damping in Pristine, Steel, and Shape Memory Alloy Hybrid Glass Fiber Reinforced Plastic Composite Beams of Equivalent Stiffness", Defence Science Journal, Vol. 68, pp. 91-97,2018.

[6] Product Data Sheet, Sikadur 52 N. https://irn.sika.com/dms/getdocument.get/bfb30323-c047-331a-a5f1- 29ce266bde3f/Sikadur\%2052.

[7] Product Data Sheet, Kellogg's Research Labs. http://www.kelloggsresearchlabs.com/

[8] Product Data Sheet, Glass Fiber Technology Co. Ltd. http://frptechnology.com/

[9] Robert M. Jones, "Mechanics of Composite Materials", Second Edition' Book, Taylor and Francis, 1999.

[10] P. Hagedorn and A. Das Gupta, 'Vibration and Waves in Continuous Mechanical Systems', John Wiley and Sons Ltd, First edition, 2007. 


\title{
تحليل الاهتزاز لعتبات مركبة منتظمة ومستدقة ومدعمة بسبيكة ذاكرة الثكل
}

\author{
قاسم عباس عطية عمار سليم حميد باقر جبار عاصي \\ قسم الهندنسة الديكانيكية، الجامعة التكنولوجية، بغداد، العراق
}

baqer92jabbar@gmail.com 20086@uotechnology.edu.iq 20044@uotechnology.edu.iq

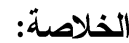

في هذا البحث تم تهجين مواد مركبة باستخدام اسلاك النتول (نيكل-تيتانيوم). تم تصنيع العينات بتقنية القولبة اليدوية، وتم

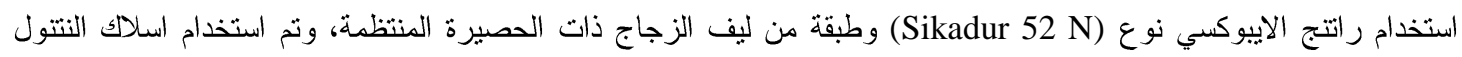

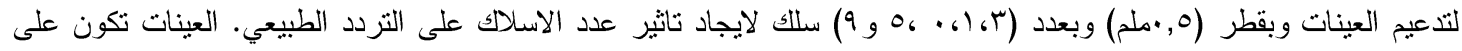

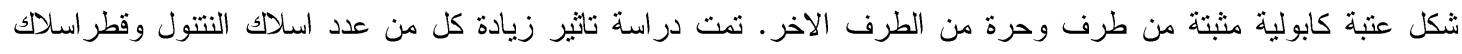

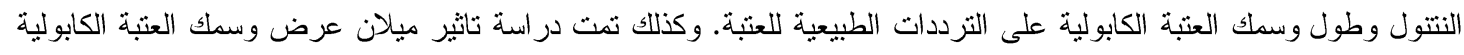

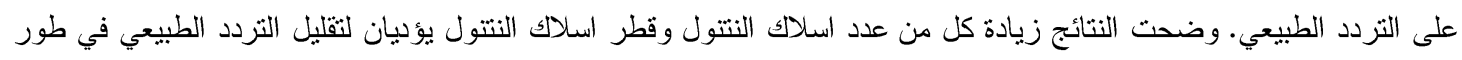

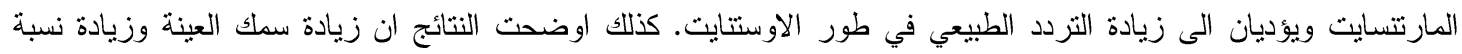

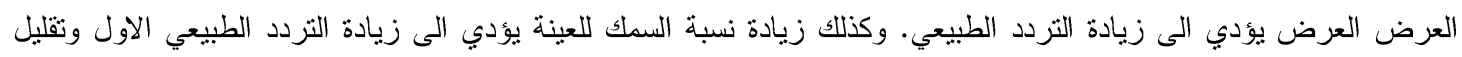
التردد الطبيعي الثاني و الثالث. وكذللك زيادة طول العينة يقلل من التزردد الطبيعي. الكلمات الاله: سبائك ذاكرة الثنكل، عتبة كابولية، التزدد الطبيعي. 